\title{
Ekonomiskā drošǐba
}

HARIJS KĀRKLINŠ, GUNĀRS VALDMANIS

Raksta mērķis ir analizēt Latvijas iedzīvotāju ekonomiskās drošības uztveri. Tradicionāli ar to tiek izprasta indivīda spēja piekḷūt nepieciešamajiem resursiem izdzīvošanai un pilnvērtīgai funkcionēšanai sabiedrībā. Apskatot gan kvantitatīvos datus, gan iegūtos kvalitatīvos fokusa grupu rezultātus šajā pētījumā, redzams, ka ekonomiskās drošības sektoru Latvijas iedzīvotāji uztver dažādi. Viena no visbiežāk minētajām problēmām ir prognozējamība. Par to liecina tas, ka viskritiskāk tiek vērtēta nodokḷu politika. Sabiedrību satrauc ne tikai lielais nodokḷu slogs, bet arī biežās nodokḷu politikas izmaiṇas. Ekonomiskā drošība tiek uztverta primāri kā ekonomiskā stabilitāte - spēja veidot uzkrājumu, iegūt nepieciešamos finanšu resursus izdzīvošanai, pensijas sistēmas uzticamība. Saistībā ar pēdējo respondenti iezīmēja neticību pietiekamu finanšu līdzekḷu iegūšanai vecumdienās. Rakstā atzīmēts, ka vērojamas būtiskas atšķirības starp fokusa grupu un pašvaldību pārstāvju viedokḷiem. Pašvaldībās ar zemāku bezdarba līmeni iedzīvotāji starp būtiskākajām problēmām minēja nodokḷu sistēmu, uzṇēmējdarbības vidi, nestabilu finanšu sistēmu, savukārt pašvaldībās ar augstāku bezdarba līmeni - transporta nozari, darba vietu skaitu, kā arī zemu minimālo algu. Savukārt pašvaldību pārstāvji intervijās norādīja uz izaicinājumiem, kas saistās ar ES fondu iespējām/finansējumu un mājokḷu pieejamības nodrošinājumu, kamēr fokusa grupās šie jautājumi parādās reti vai neparādās vispār.

Atslēgvārdi: darba tirgus, ekonomiskās drošības uztvere, nodokḷu politika, pabalsti, pensiju sistēma, uzṇēmējdarbība.

The goal of the article is to analyse the economic security perception of Latvia's inhabitants. Traditionally, economic security perception is understood as the ability of individuals to access resources needed for physical survival and for wholesome functioning within society. Analysis of both quantitative and qualitative data obtained during the study revealed that strong differences in the perception of economic security are displayed 
among societal groups. In line with the opinions voiced by the majority of the interviewed respondents, the most acute problems (with the most significant detrimental effect on the economic security perception of society) in Latvia are the low predictability of economic policy, the relatively high burden of taxes on income, the frequent changes in tax policy, and the low reliability of the pension system. Most point out that their economic security perception is closely related to their economic stability specifically, the individual's ability to obtain economic means for survival, the ability to make savings, and to have access to sufficient financial resources after retirement. The interviews involved representatives from municipalities and societal groups in municipalities with distinct differences in economic and social development, and they suggest significantly divisive opinions among residents of economically stronger versus weaker municipalities. In municipalities with higher overall economic activity, residents identify the priority issues to be the stability of tax/financial systems and a strong entrepreneurial environment, while residents of municipalities with lower economic activity point out the accessibility of public transport, creation of jobs and guaranteed minimum income for workers. Meanwhile, municipal representatives outlined the main economic issues to be the availability of housing and access to state budget support and European Union funds for investments.

Keywords: labour market, economic security perception, tax policy, social benefits, pension system, entrepreneurship.

\section{levads}

Ekonomiskā drošība politikas pētỉjumos tradicionāli tiek izprasta kā indivīda spēja piekḷūt un sevi nodrošināt ar resursiem, kas nepieciešami indivīda izdzīvošanai, kā arī pilnvērtīgai funkcionēšanai sabiedrībā. ${ }^{1}$ Valsts gadījumā tā ir valsts spēja nodrošināt resursus ekonomiskās politikas īstenošanai, veicinot valsts iedzīvotāju ekonomisko un kopējo drošību. ${ }^{2}$ Ekonomiskā drošība ir cieši saistīta ar visām citām drošības jomām, piemēram, sociālo drošîbu, militāro drošību, kiberdrošību, jo daudzos gadijumos tieši primāro ekonomisko resursu pieejamība pasākumu veikšanai citās jomās ir izškiriroša tam, lai valsts spētu stiprināt savas militārās spējas, veicināt sociālo drošību, sekmīgi ierobežot un samazināt dabas katastrofu un citu līdzīgu drošības draudu sekas. ${ }^{3}$

1 Buzan, B. (1991). People, States and Fear: An Agenda for International Security Studies in the PostCold War Era. London: Harvester Wheatsheaf.

2 Stone, M. (2009). Security According to Buzan: A Comprehensive Security Analysis. Security Discussion Papers, 11.

3 Suarez, Marcial A. \& Acacio, I. (2014). Reflections on Virtual to Real: Modern Technique, International Security Studies and Cyber Security Environment. 10.1007/978-3-642-37481-4_15. 
Kā būtiskākie ekonomiskie resursi jeb faktori, kuru pieejamība visvairāk nosaka indivīda un valsts ekonomisko drošỉbu un ilgtermiṇā arī atstāj ietekmi uz valsts makroekonomisko attīstỉbu, ir jāmin šādi ekonomiskie resursi: brīvība nodarboties ar uzṇēmējdarbību un izvēlēties nodarbinātības jomu; stabila un uzticama monetārā sistēma; finanšu un kapitāla tirgus sistēma, kas nodrošina nepieciešamos aizṇēmumus indivīdiem un uzṇēmumiem, kā arī nodrošina iespēju veikt drošus uzkrājumus; prognozējama un attīstīta nodokḷu sistēma. ${ }^{4}$ Ir būtiski atzīmēt, ka ievērojama ietekme uz ekonomikas attīstību un ar to saistīto ekonomisko drošîbu ir ne tikai uzskaitītajiem faktoriem, bet arī iedzīvotāju subjektīvajai uztverei un attieksmei pret minētajiem ekonomiskajiem resursiem - piemēram, ja sabiedrībā valda viedoklis, ka konkrētas valsts nodokḷu slogs ir augsts un netaisnīgs, tas būtiski ietekmē sabiedrības uzņēmējdarbības aktivitāti, ēnu ekonomikas īpatsvaru un iedzīvotāju mobilitāti darba tirgū, un tā iespaidā ir iespējama situācija, ka valstīs ar līdzīgu uzṇēmējdarbības vispārējo regulējumu un līdzīgu nodokḷu slogu uz ekonomiku sabiedrības kopējā ekonomiskā aktivitāte būtiski atškiriras. ${ }^{5}$ Svarīgi arī atzīmēt, ka ekonomiskā drošība visos gadījumos ir cieši saistīta arī ar citām drošỉbas jomam un, piemēram, sabiedrības ekonomiskās drošības uztvere var būtiski mainīties arī citu drošības aspektu pārmaiṇu rezultātā, kā arī ietekmēt sabiedrības drošības uztveri citās drošības jomās.

Šì raksta mērkịis ir, balstoties uz iedzīvotāju fokusa grupās veiktajām intervijām, iegūt priekšstatu par Latvijas iedzīvotāju ekonomiskās drošības uztveri un par to, cik no ekonomiskās drošības viedokḷa droši jūtas dažādu Latvijas pilsētu iedzīvotāìi, identificējot problēmas, kuras Latvijas iedzīvotāju skatījumā ekonomiskās drošỉbas jomā ir vērtējamas kā aktuālākās, un cik lielu nozīmi šo ekonomiskās drošîbas problēmu risināšanā iedzīvotāji pieškir valstij un pašvaldībai, kā arī aprakstìt atškirības un to iespējamos cēloṇus, kas vērojamas dažādu Latvijas pašvaldību iedzīvotāju ekonomiskās drošỉbas uztverē.

\section{Kas paveikts ekonomiskās drošības izpētē?}

Ekonomiskā drošība ir viena no jomām, kurā tiek veikti gan regulāri sabiedrïbas attieksmes mērījumi, gan arī ekonomisko indikatoru apkopošana un analīze, kas nepieciešamas, lai izprastu indivīda drošības subjektīvo uztveri.

4 Tamošiūnienè, R. \& Munteanu, C. (2015). Current research approaches to economic security, pp. 62-65. 10.4995/ICBM.2015.1537.

5 Roberto Dell'Anno (2009). Tax evasion, tax morale and policy maker's effectiveness. The Journal of Socio-Economics, 38(6), pp. 988-997. Pieejams: https://doi.org/10.1016/j.socec.2009.06.005. 
Ar augstu regularitāti un pēc vienotas metodologijas iedzīvotāju un uzņēmēju viedokḷa aptaujas un noskaņojuma mērïjumi tiek veikti visā Eiropas Savienībā (ES). Tas ļauj šajā pētỉjumā iegūtos datus un viedokḷus salīdzināt ar līdzīgu pētījumu datiem. Šajā pētījumā par būtisku atskaites punktu var uzskatīt 2019. gada rudenī Eirobarometra (Eurobarometer) veikto ES iedzīvotāju aptauju par nozīmīgākajiem draudiem, ar kuriem saskaras ES un tās dalībvalstis. ${ }^{6}$ Aptaujā ES iedzīvotājiem tradicionāli tikai uzdoti jautājumi par ekonomisko situāciju un diviem lielākajiem draudiem, ar ko nākas saskarties ES kopumā un dalībvalstīs atseviški.

1. attēlā ir redzams, ka Latvijas iedzīvotāji savu personisko situāciju vērtē līdzvērtīgi kā visi ES dalībvalstu pilsoṇi (darba jomā pat nedaudz augstāk), tomēr kopējo valsts situāciju vērtē negatīvāk.

Ja salīdzina aptaujā norādītās atbildes un jautājumiem par galvenajām problēmām, ar ko saskaras ES kopumā un attiecīgā dalībvalsts, redzams, ka Latvijas iedzīvotāji ekonomikas jomas problēmas uztver prioritārāk nekā ES iedzīvotāji, ja jautājums ir par pašu dalībvalsti, nevis ES kopumā. Aptaujā tika piedāvāti 13 dažādi atbilžu varianti par aktuālāko ES problēmu, un seši no tiem ir saistìti ar ekonomisko drošību plašākā izpratnē (ekonomiskā situācija, dalībvalstu publisko finanšu stāvoklis, nodarbinātība, inflācija / augošās izmaksas, pensijas, nodoklii).

2. attēlā redzams, ka, salīdzinot ar ES valstīm kopumā, Latvijā iedzīvotāju viedoklis par problemātiskākajiem jautājumiem ekonomiskās drošības jomā būtiski neatšḳiras no ES dalībvalstu iedzīvotāju viedokḷa vidēji, - tādu iedzīvotāju skaits, kuri ar ekonomiku saistìtus jautājumus min starp ES nozīmīgām problēmām, ir bijis līdzīgs un nedaudz zemāks nekā Eiropas Savienībā kopumā, vienlaikus nedaudz pesimistiskāk vinii vērtē nodokḷu sistēmas problēmas, bet nedaudz optimistiskāk - nodarbinātības situāciju.

3. attēlā atspoguḷoti ES dalībvalstu lokālie kritiskie jautājumi, kuri, pēc iedzīvotāju domām, ir visnozīmīgākie un ir saistīti ar ekonomikas jomu. Ja salīdzina ar ES vidējo situāciju, tad redzams, ka jautājumi, kas saistīti ar ekonomiku un finansēm, vairāk satrauc Latvijas, nevis citu valstu iedzīvotājus. Kā galveno kritisko problēmu Latvijā 43\% tās iedzīvotāju norādījuši "Veselību un sociālo drošîbu”. Kā otru galveno - inflāciju / augošās izmaksas (29\%), savukārt 3. vietā ir nodokḷi (24\%, tas ir 2. augstākais rādītājs ES aiz Lietuvas, ar kuru kopā Latvija ir vienīgās dalībvalstis, kuru iedzīvotāii norādīja uz nodoklịem kā starp trim galvenajiem problemātiskajiem jautājumiem). Analogas

6 European Commission (2018). Europeans' attitudes towards cyber security. Pieejams: https://op. europa.eu/en/publication-detail/-/publication/468848fa-49bb-11ea-8aa5-01aa75ed71a1 


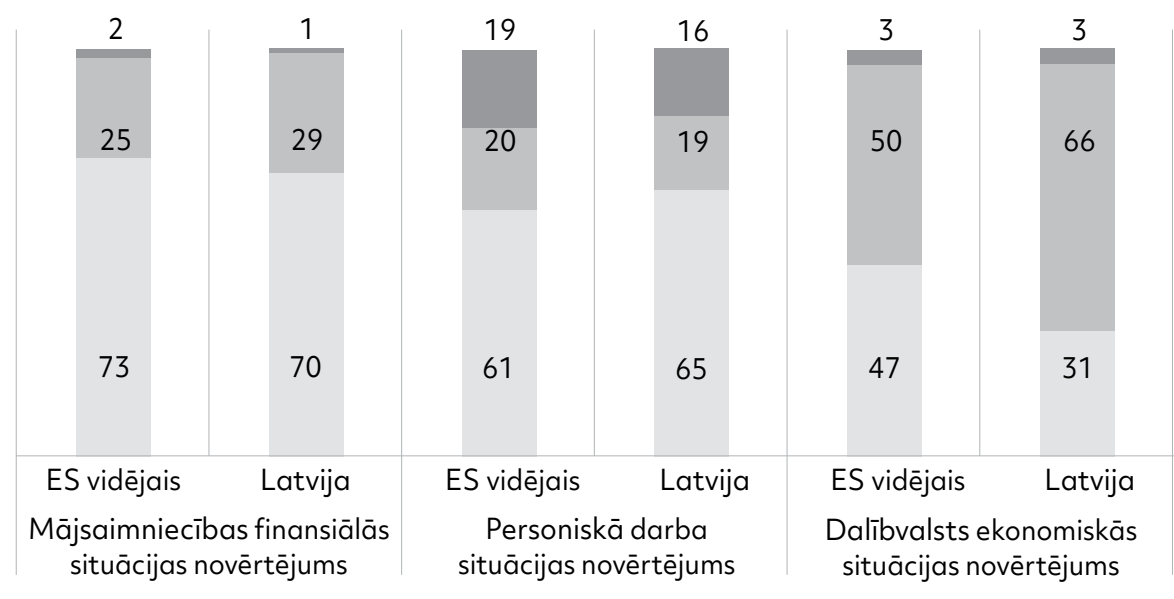

Labi Slikti $\quad$ Nezinu

1. attēls. ledzìvotāju ekonomiskās situācijas novērtējuma salīdzinājums starp ES dalībvalstu vidējo un Latviju, \%

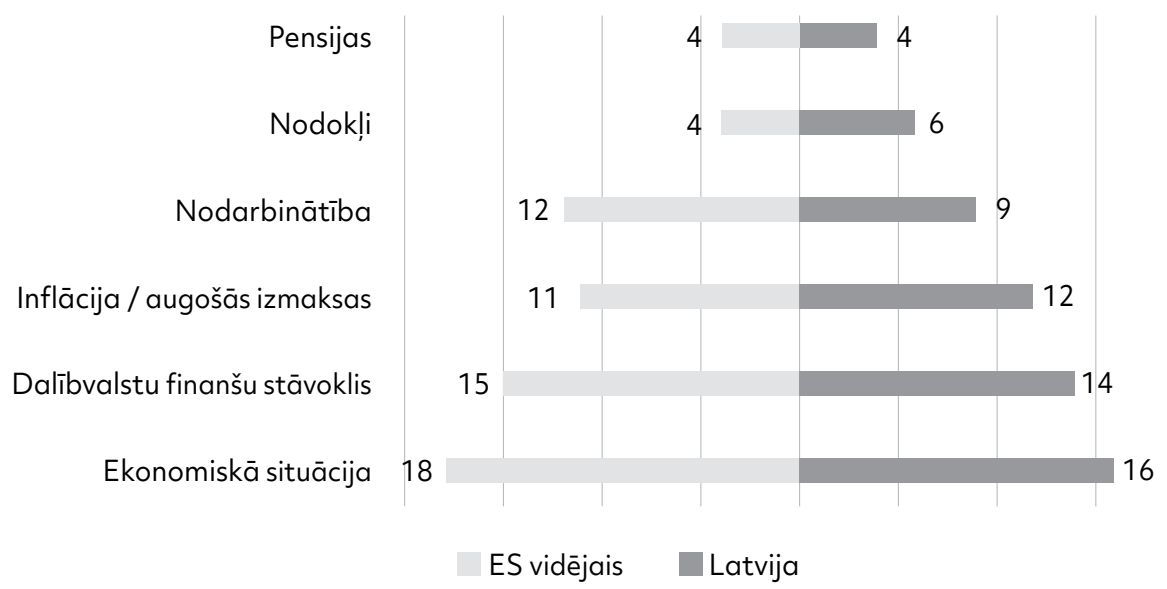

2. attēls. Ekonomikas jomas galvenie jautājumi, ar ko pašlaik saskaras Eiropas Savienība kopumā, iedzīvotāju vērtējumāā, \%

būtiskākās problēmas Latvijas iedzīvotāji bija minējuši arī 2019. gada pavasara Eirobarometra aptaujās, turklāt nodokḷu sistēma kā problēma 2019. gada pavasarī Latvijā, salīdzinot ar citām ES dalībvalstīm, tika minēta visbiežāk. ${ }^{7}$

7 Eurobarometer 91 (2019. gada pavasaris). Pieejams: https://data.europa.eu/euodp/lv/data/dataset/ S2253_91_5_STD91_ENG 


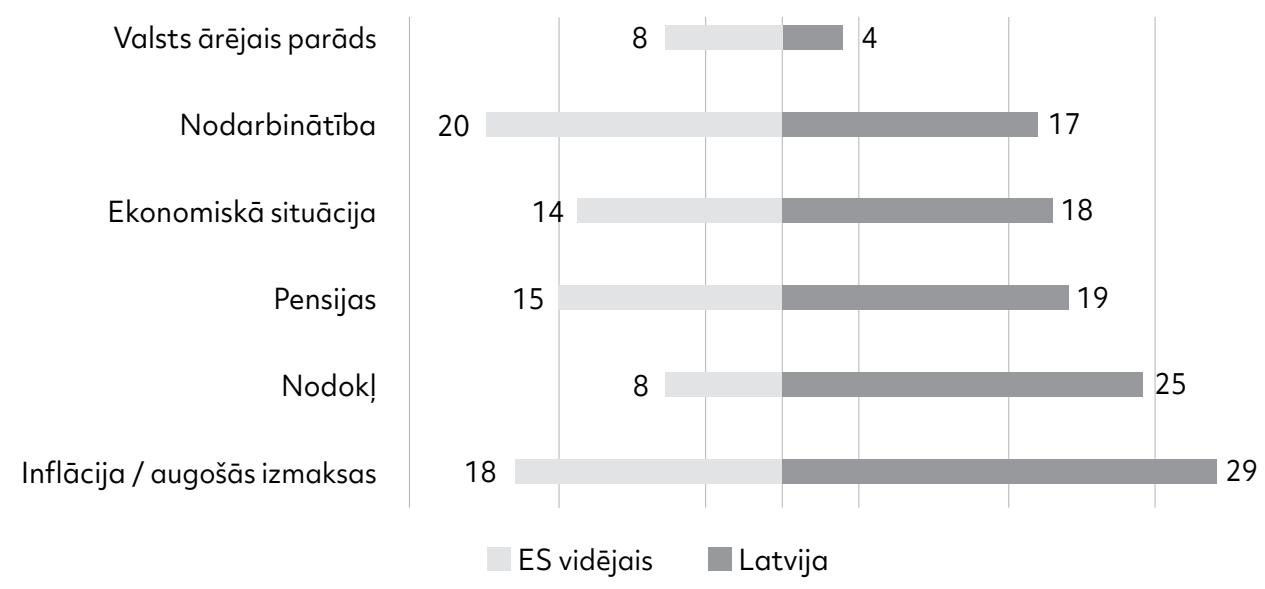

3. attēls. Ekonomikas jomas galvenie jautājumi, ar ko pašlaik saskaras ES dalībvalstis, to iedzivotāju vērtējumā, \%

Padziḷinātāku ieskatu apsvērumos, kuri Latvijas iedzīvotājus mudina ekonomiskās drošības problēmas uzskatīt par kopumā sev nozīmīgākām, nekā uzskata citu ES valstu iedzīvotāji, sniedz arī vairāki Latvijā veikti pētỉjumi un sabiedriskās domas aptaujas, kur norādīts, ka, gan pēc pašu iedzīvotāju, gan arī pēc ekonomistu vērtējuma, Latvijā ir salīdzinoši augsts iedzīvotāju nabadzības risks un ienākumu nevienlīdzība. 2019. gada aprīlī publicētais Centrālās statistikas pārvaldes pārskats par ienākumiem apliecina, ka, par spīti vidējās algas pieaugumam tautsaimniecībā, aug arī to iedzīvotāju skaits, kas ir pakḷauti nabadzības riskam, - šis rādītājs 2019. gadā sasniedzis 23,3\% pretstatā 19\% 2010. gadā. Lai gan 2020. gada janvārī publicētie analoǵiskie pētỉjuma dati uzrāda nelielu uzlabojumu un nabadzības riskam pakḷauto iedzīvotāju skaita samazināšanos līdz 22,9\%, rādītājs joprojām ir vērtējams kā augsts.

Nabadzības riskam pakḷauto iedzīvotāju grupu padzilināăta analīze norāda uz to, ka šādu iedzīvotāju īpatsvars visstraujāk palielinās pensijas vecumu sasniegušu cilvēku vidū, savukārt tas samazinās gados jauniem cilvēkiem ar bērniem un vienas personas mājsaimniecībām darbspējīgajā vecumā. Kā būtiskas nabadzības risku raksturojošas pazìmes pētỉjumā var identificēt augstu sociālo transfertu īpatsvaru mājsaimniecību ieṇēmumu grozā, jo kopumā sociālo transfertu apjoma pieaugums ir lēnāks nekā daudzu citu makroekonomisko rādìtāju pieaugums, piemēram, vidējo darba algu pieaugums un patēriņa cenu pieaugums, starpības palielināšanās starp vienam mājsaimniecības loceklim nepieciešamo un faktiski pieejamo ienākumu apjomu (555 EUR pretstatā 488 EUR) ḷoti būtiskā skaitā mājsaimniecību (aptuveni $70 \%$ no visām 
mājsaimniecībām). Tāpat arī jāmin pazīme, kas ir raksturīga augstam nabadzības riskam, - iedzīvotāju nespēja segt neparedzētus izdevumus un finansēt ilglietojamo patēriņa preču iegādi, piemēram, mēbel̦u iegādi. ${ }^{8}$

Veiktie pētījumi par nabadzības riskam pakḷauto iedzīvotāju skaitu ir būtiski, jo, pirmkārt, tie ḷauj precizēt iedzīvotājiem aktuālās problēmas un iegūt vispārīgu ieskatu par iedzīvotāju attieksmi pret tām un, otrkārt, tie ḷauj arī identificēt un nodalìt vairākas atsevišķas iedzīvotāju grupas, kurām ir atšķirīgas ekonomikas drošības problēmas, un padzilinināti novērtēt šo sabiedrības grupu atbildes jau tālākajā pētījuma gaitā. Iepriekšējie pētījumi par nabadzības risku ḷauj izcelt divas būtiski atšķirīgas iedzīvotāju grupas, kurām aktuālie ekonomiskās drošības izaicinājumi ievērojami atšķiras, - ekonomiski aktīvos iedzīvotājus darbspējīgā vecumā, kā arī ekonomiski mazāk aktīvo sabiedrības dalıu, piemēram, pensiju saņēmējus un atsevišķos gadījumos mājsaimniecības ar bērniem, kurās ir tikai viens pieaugušais, kā arī iedzīotājus ar zemāku izglìtības un profesionālās sagatavotības līmeni. Atsevišķi ir vērtējams apstāklis, ka atbilstoši pētỉjumu rezultātiem joprojām satraucoši augsts ir arī tādu iedzīvotāju īpatsvars, kuru mājsaimniecības, par spīti aktīvai dalībai darba tirgū, gūst ieņēmumus tikai minimāli nepieciešamajā apjomā uz vienu mājsaimniecíbas locekli vai pat zem šì apjoma.

\section{Ekonomiskās drošības jēdziens}

Ekonomisko drošỉbu kā vienu no drošỉbas politikas aspektiem plašāk un padziḷinātāk ir definējis angḷu politologs, drošības jautājumu pētnieks Barijs Buzans (Barry Buzan), kurš zināmā mērā pārskatijja tradicionālo pieeju ekonomiskās drošỉbas izpratnei par to, ka ekonomiskā drošỉba ir, pirmkārt, valsts ekonomiskā kapacitāte nodrošināt nepieciešamo finansējumu aizsardzības spējām un militārajam sektoram. Buzans ekonomisko drošību saista ar pieeju svarīgākajiem resursiem, finansēm un tirgiem, kuri ir nepieciešami, lai valstī nodrošinātu pieņemamu labklājības un varas līmeni. ${ }^{9}$ Vienlaikus autors atzīmē ekonomiskās drošības abstrakto un nekonkrēto raksturu, uzsverot, ka ekonomiskās drošības izpratnes definēšanu konkrētā valstī var ietekmēt gan atsevišķu iesaistīto pušu attiecības ar tirgu, gan individuālās vēlmes, gan arī dialogs starp iesaistītajām pusēm, politikas veidotājiem, piemēram, valsts pārvaldes

8 Vairāk nekā trešdaḷa mājsaimniecību nemaina mēbeles, kad tās ir nolietotas, ap 60\% mājsaimniecību 2018. gadā nevarēja atḷauties segt neparedzētus izdevumus līdz 320 eiro.

9 Buzan, B. (1991a). People, States, and Fear: The National Security Problem in International Relations. Wheatsheaf Books Ltd. 
struktūrām un politiskajām organizācijām, un ekonomiski aktīvo sabiedrības daḷu, darba devējiem un ñēmējiem. ${ }^{10}$

Savukārt Amerikas Universitātes Starptautiskā dienesta skolas docents Mamuka Ceretelli (Mamuka Tsereteli) uzsver ekonomisko drošības ilgtspējas nozīmi un pasvītro, ka valstu ekonomiskā drošỉba ir ilgtermiņa pieeja ekonomiskajām iespējām tirgū un nepieciešamajiem resursiem, ieskaitot cilvēkus, kapitālu, enerǵiju, ūdeni, tehnoloǵijas un izglîtību. ${ }^{11}$ Vienlaikus pētnieks lielu nozīmi piešķir arī ekonomiskajai brīvībai, proti, sabiedrības locekḷu tiesībai un iespējām brīvi izvēlēties savas ekonomiskās aktivitātes, kā arī valsts spējai îstenot politiku, kas stabilizē ekonomiku un labklājību. Treškārt, Ceretelli kā būtisku ekonomiskās drošības aspektu saskata arī valsts spēju aizstāvēt savas un tās iedzìvotāju un uzṇēmēju ekonomiskās intereses attiecībās ar citām valstīm. Tāpat pētnieku, piemēram, Brendas Horiganas (Brenda L. Horrigan) un Teodora Karasika (Theodore Karasik), darbos ekonomiskā drošiba tiek cieši saistīta arī ar citu drošības politikas jomu veiksmīgu isstenošanu - tiek uzsvērts, ka ekonomiskās drošības samazinājums negatīvi ietekmē, piemēram, sociālo drošỉbu, samazina sabiedrības uzticēšanos valsts pārvaldei un vēlētajiem politiķiem, kā arī var pamudināt sabiedrību mazāk aktīvi atbalstīt valsts īstenoto politiku ārējās drošības jomā (var būt spiediens samazināt aizsardzības izdevumus vai pārskatīt valsts īstenoto ārpolitiku attiecībās ar ārpolitiskajiem partneriem).

Tāpēc šajā pētijumā ekonomiskās drošỉbas uztveres analīzei, balstoties uz iepriekš aprakstìtajiem datiem un teorētiskajiem pètījumiem, ir izvēèèti šādi sabiedrības ekonomiskās drošības uztveres aspekti ar attiecīgajiem pamatojumiem:

1) iespējas brīvi iesaistīties darba tirgū un nodarboties ar uzṇēmējdarbību - liecina par iedzīvotāju ekonomisko pratību, tautsaimniecības spēju pielāgoties iekšējām un ārējām pārmaiṇām, kā arī valsts ekonomisko izaugsmi un iedzīvotāju ienākumu līmeni;

2) tautsaimniecības struktūras ilgtspēja un spēja pielāgoties lokālām un globālām pārmaiṇām - diversificētām valstu ekonomikām ir ievērojami augstāka spēja pārvarēt krīzes, jo būtiskākā daḷa no tām parasti smagāk skar atsevišķas tautsaimniecỉbas nozares. Piemēram,

10 Buzan, B., Waever, O. and de Wilde, J. (1998). Security: A New Framework for Analysis, Lynne Rienner Publishers, Inc, Boulder, Colorado.

11 Tsereteli, M. (2008). Economic and Energy Security: Connecting Europe and the Black Sea-Caspian Region. Central Asia-Caucasus Institute and Silk Road Studies Program, Singapore. Pieejams: http://www.silkroadstudies.org/resources/pdf/SilkRoadPapers/2008_03_SRP_Tsereteli_EnergyBlack- Sea.pdf [Skatīts 30.04.2020.] 
lauksaimniecības nozari proporcionāli būtiskāk skar tieši dabas apstākḷi, savukārt tūrisma un naftas ieguves nozares - drošības situācijas pasliktināšanās, tāpēc no valstu ekonomiskās stabilitātes viedokḷa ir būtiski, lai tās lielāko daļu nodarbinātības un ieṇēmumu neveidotu viena šauri specifiska ekonomiskā aktivitāte;

3) valsts spēja ierobežot globālu ekonomisko norišu negatĩvo ietekmi uz tautsaimniecību un spēja gūt pēc iespējas lielāku labumu no pozitīvām globālām ekonomiskām norisēm - raksturo kopējo ekonomiskās politikas efektivitāti un elastību, piemēram, spēja un gatavība novērtēt ārējo konkurētspēju noteicošos faktorus un veikt tiem atbilstošas korekcijas normatīvo aktu bāzē un faktiskajā valstu rīcībpolitikā, piemēram, veicinot ārējo tirdzniecỉbu ar jauniem ārējās tirdzniecības partneriem;

4) nodokḷu sistēmas un publiskās pārvaldes ietekme uz uzṇēmējdarbỉbu un ekonomisko aktivitāti - priekšnosacijums tam, lai valstī veidotos uzņēmējdarbībai labvēlīga vide un lai iedzìvotāju vērtējumā nodokḷu slogs un tiesiskais regulējums motivētu indivīdus sākt patstāvīgu uzṇēmējdarbību vai profesionālo darbību augsti atalgotā tautsaimniecības jomā;

5) valsts sociālo transfertu sistēma - pensija un pabalsts sociāli neaizsargātākajai daḷai ir galvenais vai nereti vienīgais ienākumu avots. Šīs sistēmas efektīva funkcionalitāte veicina iedzīvotāju daḷas izkḷūšanu no nabadzības riska zonas;

6) finanšu sistēmas drošība un spēja iegūt finanšu aizdevumu, uzkrājumus - kredītiestāžu sistēmu drošība ir būtiska, lai garantētu iedzīvotājiem drošỉbu. Savukārt informācija par finanšu aizdevumu pieejamību ilgtermiṇa lietošanas preču un mājokḷu iegādei sniedz salīdzinoši objektīvāku ieskatu par to, cik stabili, prognozējami un pietiekami primāro vajadzību apmierināšanai ir iedzīvotāju ienākumi. Turklāt spēja saṇemt finanšu aizdevumu mājokḷa iegādei būtiski ietekmē arī indivīda nākotnes ekonomiskās drošības novērtējumu, jo mājokḷa iegādi ar finanšu aizdevumu palīdzību var uzskatīt par iespēju vairot ekonomisko labklājību, savukārt mājokḷa īre lielākajā dạ̦ā gadījumu tikai apmierina indivīda primārās vajadzības, nenodrošinot ekonomisko resursu uzkrāšanas iespēju. 


\section{Latvijas iedzivotāji par ekonomisko drošību}

Pētỉjuma gaitā fokusa grupās iegūtie iedzīvotāju viedokḷi apstiprināja citos pētỉjumos gūtos novērojumus par to, ka Latvijas iedzīvotāji ekonomisko drošîbu uzskata par vienu no nozīmīgākajiem drošības aspektiem un kopumā dažādās fokusa grupās iegūtie iedzīvotāju viedokḷi norāda, ka ekonomiskās drošības uztveres atšķirības iedzīvotāju vidū dažādās pašvaldībās un reǵionos ir nebūtiskas. Praktiski visās fokusa grupās uz jautājumu "Ko jums nozīmē drošība?" bieži tika saṇemtas tādas atbildes kā "ekonomiskā stabilitāte", "finansiālā drošība", "materiālā stabilitāte un fiziskā drošība". Ekonomiskā stabilitāte kā drošỉba tika minēta astoṇās no 12 fokusa grupām, ${ }^{12}$ kḷūdama par vienu no visbiežāk sastopamajām frāzēm.

Iedzīvotāji izsaka neapmierinātību ar algām, pensijām, pabalstiem, nodokḷu politiku un citiem faktoriem. Turklāt ekonomiskā sektora nozīmīgums parādās arī, vērtējot situāciju citu jomu drošībā, piemēram, sociālajā drošîbai, vides drošībā, militārajā drošībā, jo tiek uzsvērts, ka ekonomiskā drošība ir būtiskākais priekšnosacījums tam, lai sabiedrība un valsts pārvaldes struktūras spētu veikt nepieciešamos pasākumus vides un dabas katastrofu apdraudējumu novēršanai, militāro draudu samazināšanai un sociālās drošības instrumentu stiprināšanai.

Vīrietis, Aizkraukle: Klimata pārmaiņas neuztveru kā draudu savai personiskajai drošizai. Nešksiet, ka tas uz mani attiecas, un neuzskatu, ka tā būtu Latvijā ḷoti milzīga problēma. Latvijai tas drīzāk noteiktās jomās nāktu par labu. Palielināsies ražība, pazemināsies cilvēku slimošana ar ziemas perioda slimībām. Mazāki rēkini par apkuri.

Vīrietis, Jaunjelgava: Cilvēk' iestājas NBS dēl naudas.

Neskatoties uz ekonomiskās drošības jautājumu augsto prioritāti praktiski visās pašvaldībās, kurās tika veikts pētījums, dažās ievērojami atšķīās izpratne par nozīmīgākajām problēmām un resursu pieejamību to risināšanai pašvaldībās ar augstākiem vidējiem ienākumiem un zemāku bezdarba līmeni (Aizkraukle, Rīga) iedzīvotāji starp būtiskākajām problēmām minēja nodokḷu sistēmu, uzṇēmējdarbības vidi, stabilu finanšu sistēmu, kā arī darbaspēka emigrāciju, savukārt pašvaldībās ar salīdzinoši augstāku bezdarba līmeni (Rēzekne, Daugavpils) būtiskas problēmas bija atsevišķu ekonomikas sektoru darbības rezultāti (piemēram, transporta nozare), darba vietu skaits, iedzīvotāju emigrācija, kā arī zema minimālā alga. 
Tālāk tiek sīkāk aprakstīti iegūtie rezultāti pa dažādām ekonomikas jomām, kuras iedzīvotāji fokusa grupās minējuši visbiežāk, - finanšu un banku sistēma, darba tirgus, nodokḷ sistēma un administratīvais slogs, publiskās investīcijas, reǵionālās attīstības politika, kā arī sociālās apdrošināšanas sistēmas darbiba.

\section{Ekonomiskā stabilitāte - ienākumi un uzkrājumi}

Kā atsevišķs ekonomiskās drošības riska faktors, kuru salīdzinoši bieži pieminējuši iedzīvotāji lielākajā dạ̦ā pašvaldību, ir ekonomiskā stabilitāte, kas tiek saistīta gan ar iedzīvotāju un uzṇēmēju iespējām veikt aizṇēmumus un veidot uzkrājumus, gan ar iedzīvotāju iespējām izpildīt uzņemtās saistības. Kopumā finanšu sektora stabilitāte iedzīvotāju skatījumā ir apmierinoša. Lai gan finanšu sektorā ir vērojami skandāli un ekonomiskās grūtības, iedzīvotāji riskus, kas ir saistīti ar kredītiestāžu darbu, vērtē kā iespējamus, tomēr maz ticamus. Kredītiestāžu darbības satricinājumu risks iedzīvotāju vērtējumā ir uzskatāms par zemu galvenokārt tāpēc, ka finanšu sektors daḷēji tiek uzraudzìts arī Eiropas Savienības līmenī, turklāt valsts noguldïjumu garantiju sistēma būtiski samazina iedzīvotāju riskus saistībā ar uzkrājumu drošību kredītiestādēs.

Savukārt par kritisku problēmu tiek uzskatìta iedzīvotāju nespēja pildīt savas saistības, it īpaši īstermiņa kredītu gadījumā, un, pēc aptaujāto domām, salīdzinoši liberāla valsts un uzṇēmēju politika ir veicinājusi nesamērīgi dārgu un pārāk viegli pieejamu kredītu izsniegšanu iedzīvotājiem, šādi apdraudot sabiedrības ekonomisko drošību, veicinot mazāk turīgo sabiedrības locekḷu maksātnespēju un sekojošu emigrāciju. Iedzīvotāji nereti norāda uz to, ka ekonomiskā stabilitāte ir galvenā problēma, jo

a) ja nebūs līdzeklu, cilvēkus vieglāk pamudināt uz kaut kādām darbībām;

b) tie, kas aizbrauc [strādāt uz ārzemēm], negrib mainìt ekonomisko stabilitāti pret dzimtenes mīlestību.

Vairākās fokusa grupās (piemēram, Ādažos, Jaunjelgavā un Aizkrauklē) pensijas vecuma iedzīvotāji norādīja, ka kopumā ilgtermiṇā neuzticas valsts pensiju sistēmai, jo prognozēe, ka, migrācijas rezultātā pakāpeniski samazinoties darbspējīgo iedzīvotāju skaitam valstī, budžeta ieņēmumi kḷūs nepietiekami, lai nodrošinātu pensiju sistēmas tālāko darbību. Tāpat atsevišḳās fokusa grupās (piemēram, Aizkrauklē) tika kritizēta pansionātu kvalitāte. Bez tam četrās fokusa grupās respondenti arī norādīja, ka nākotnē būtiski nepaḷaujas uz iespēju, ka iztikai nepieciešamos līdzekḷıs vecumdienās varētu nodrošināt tuvinieku, piemēram, bērnu, atbalsts. Atsevišķ̧os gadījumos iedzīvotāji atzīst, ka ilgtermiṇā ekonomisko drošību veicinātu arī uzkrājumu veidošana, tomēr, 
viņuprāt, nepietiekamu ienākumu dēl šobrīd šādas iespējas ir ierobežotas lielai dal̦ai sabiedrības. Kopumā pašvaldībās arī izskan iedzīvotāju viedoklis, ka minēto iemeslu dẹl kopumā iedzīvotāju labklājỉba var pasliktināties, - kā norāda kāda intervēta sieviete no Talsiem, nabadzība plauks. Vienlaikus pietiekami bieži izskan iedzīvotāju viedokḷi arī par to, ka ekonomiskās drošības nodrošināšana lielā mērā ir arī viṇu pašu atbildība un par savu ekonomisko labklājỉbu un ienākumiem iedzīvotājiem ir jārūpējas, plānojot savu nākotnes karjeru un izvēloties arī dzīvesvietu. Piemēram, vīrietis no Madonas uzsver, ka dą̧a iedzīvotāju, ņemot vērā atalgojuma apsvērumus, labprāt iestājas Nacionālajos bruṇotajos spēkos.

Ir vērojams arī, ka pašvaldībās ar augstāku dzīves līmeni un zemāku bezdarbu iedzīvotāji biežāk uzskata, ka ekonomiskā labklājība un ekonomiskā drošība primāri ir uzskatāmas par indivīda atbildību, ieskaitot uzņēmējdarbību, darba vietu radīšanu, noteikta ienākumu līmeņa uzturēšanu, savukārt valstij un pašvaldībai ir jānodrošina nepieciešamie priekšnosacijumi, lai indivīds spētu sevi ekonomiski realizēt, veicinot iedzīvotāju iesaistīšanos uzṇēmējdarbībā vai arī augstas profesionālas kvalifikācijas iegūšanu.

Savukārt pašvaldībās ar zemāku ienākumu līmeni un augstāku bezdarba līmeni iedzīvotāji salīdzinoši biežāk ir pauduši viedokli, ka viņu ekonomiskā labklājỉba un uzṇēmējdarbības attīstìba ir primāri valsts un pašvaldību atbildība, kurām ideālā gadījumā būtu jāgarantē iedzīvotāju spējām un prasmēm atbilstošu darba vietu pieejamība. Pamanāmas bija arī atšķirības, kā iedzīvotāji izprot uzṇēmējdarbības nozīmi ekonomikas drošības veicināšanā, - pašvaldībās ar augstu ienākumu līmeni un zemu bezdarbu uzṇēmējdarbība tika primāri uztverta kā nozīmīgākais ekonomiskās labklājības un drošības dzinējspēks un neatṇemama kopējās saimnieciskās dzīves sastāvdaḷa, turpretī pašvaldībās ar augstāku bezdarbu biežāk vērojama pretrunīga un duāla attieksme, uzṇēmēji nereti tiek pretnostatìti darba ņēmējiem, tiek uzsvērts īpašs uzn̦ēmēju pienākums rūpēties par pārējo sabiedrību līdzīgi kā valstij un pašvaldībām un netieši pausts viedoklis, ka valstij un pašvaldībām ir jāuzrauga, lai uzṇēmēji šo pienākumu pildītu.

Respondenti no Gulbenes: Darbu nevar atrast, tāpēc padomju laiks bija mierīgāks.

Jädomā pašvaldībām, valstìm, kā taisìt darba vietas, nevis izklaides vietas.

Finanšu sektors ir visnestabilākais. Privāto firmu aiztaisa ciet - darbinieki zaudē darbu. Valsts darbinieku sektorā situācija it kā ir stabilāka/drošāka.

Pretrunīgāks viedoklis ir par pabalstiem, kas tiek izmaksāti nenodarbinātām personām. Lai gan tiek kritizēta indivīdu ienākumu un uzkrāšanas 
iespējas kopumā valsts līmenī, tieši pabalstu izmaksāšana tiek kritizēta kā pārāk dāsna un izškēèdīga, jo neveicina nodarbinātību, tieši pretēji - motivē cilvēkus nestrādāt, jo finansiālais papildu ieguvums strādājot ir salīdzinoši neliels. Tāpat tiek veltìta kritika dažādu kursu rīkošanai, kuru primārais mērķis - samazināt bezdarbu - netiek sasniegts. Tos uztver kā pabalsta iegūšanas veidu. Turklāt šo kursu rīkotāji/pasūtītāji nepēta, kādas prasmes kursos var apgūt un kāds ir to pieprasijums darba tirgū. Šāds viedoklis ir novērojams tieši mazākās pašvaldībās - Ādažos, Gulbenē, Madonā, Rēzeknē.

Nepamatotas pabalsta izmaksas. Saņems cilvēks 100 EUR un nestrādās!

Kāpēc man strādāt par 400 EUR, ja es varu saņemt pabalstus par 200-300 EUR. Neatbalstu 9 mēnešu ierobežojumus.

\section{Valsts pārvalde un nodokli}

Savukārt salīdzinoši vienota izpratne iedzìvotāju vidū ir bijusi par nodokḷu sistēmu un uzṇēmējdarbības vidi, kuras visās pašvaldībās ir novērtētas kā ekonomisko un sociālo drošību apdraudošs faktors. Fokusa grupās nodokḷ sistēmas kritizēšana bija visregulārāk sastopama, tā tika kritizēta lielākajā daḷā pašvaldību. Lai gan iedzīvotāji uzskata, ka Latvijā nodokḷu likmes ir augstas un tās kavē gan iedzīvotāju labklājības uzlabošanos, gan arī uzṇēmējdarbības attīstību, vairāk tika kritizēta nodokḷ politikas nestabilitāte un regulārās izmaiṇas. Balstoties uz šo viedokli, iedzīvotāji visos Latvijas reǵionos uzskata, ka ekonomiskās drošîbas veicināšanai nodokḷu likmes būtu samazināmas un būtu jāizvairās no biežām nodokḷu likmju izmaiṇām.

Sieviete darbspējas vecumā: Latvijā ir liela dārdzība (nodokḷi, pārtika, komunālie). Tas apdraud personīgo drošību.

Respondents, Jaunjelgava: Būtu forši, ja grozìtu nodokl̦us tikai piecos gados reizi. Sieviete darbspējas vecumā, Talsi: Lielus nodokḷus maksāt tagad es neredzu jēgu, jo valstī ir nestabila nodokḷ sistēma. Reforma pēc reformas, es viniem neuzticos pilnībā. Nav ticības nodokḷu un pensiju sistēmai. Katram savā zeķēe.

Pensionārs, Talsi: Nodokliem nav perspektīvas. Nāks jauna reforma un atkal nodokḷu politiku mainīs.

Uzṇēmēja, Rìga: Valstī kopumā nav paredzamības un plānveidības. Nevienā no lìmeniem nevar paredzēt, kas notiks.

Savukārt uzṇēmējdarbības vides jomā ekonomisko drošību lielākajā dậa pašvaldību negatīvi ietekmē administratīvais slogs un birokrātija. Turklāt uzñēmējs no Talsiem norāda, ka mazinās iedzīvotāju vēlme pildīt nodokḷu saistības: 
Valsts lìmeña korupcija ir milzīgs apdraudējums. Käda jēga mums visiem maksāt nodoklus - pilnīgs bezcers. It kā tiek apsūdzētas personas, bet nekas nenotiek. Korupcija grauj vēlmi maksāt nodokḷıs.

\section{Banku sektors un to pakalpojumu pieejamība}

Kā atsevišks ekonomiskās drošỉbas riska faktors vairāku iedzīvotāju atbildēs minēts arī finanšu sektors - kredītiestādes un to darbība. Vairāki iedzīvotāji uzsver, ka finanšu sektorā iepriekš vērotie skandāli un arī kredītiestāžu maksātnespējas gadījumi risku, ka Latvijas ekonomisko stabilitāti un iedzīvotāju ekonomisko drošỉbu var apdraudēt satricinājumi banku sektorā, vērtē kā ticamu. Tomēr vienlaikus iedzīvotāji atzīst, ka kopumā riski, kas ir saistīti ar kredītiestāžu un finanšu sistēmu, ir samazinājušies Eiropas Savienības līmeņa kredītiestāžu uzraudzības ieviešanas, kā arī vienotās valūtas - eiro - ieviešanas dēḷ. Tāpat atzinīgi tiek vērtēti garantiju fonds un nerezidentu naudas samazinājums.

Vairāku pašvaldību iedzīvotāju vērtējumā savukārt par risku finanšu un kredītiestāžu sistēmu darbībai tiek uzskatīts fakts, ka lielākā daļa Latvijas kredītiestāžu pieder ārvalstu investoriem, - izskan viedoklis par to, ka ārvalstu kapitāla klātbūtne kredītiestādēs ierobežo valsts pārvaldes institūciju iespējas ietekmēt un kontrolēt to darbību sabiedrības interesēs, piemēram, ārkārtas gadījumos, kad iedzīvotājiem masveidā var rasties nepieciešamība pēc skaidras naudas. No tā var secināt, ka kopumā iedzīvotāju vērtējumā valsts ekonomisko drošību veicinātu arī ciešāka valsts kontrole pār kredītiestāžu darbību vai pat valstij piederošas kredītiestādes darbības atjaunošana. Vienlaikus atsevišķi iedzīvotāji atzīst, ka kopumā kā pozitīvu, ekonomisko drošību veicinošu apstākli vērtē to, ka Latvijas lielākās bankas pieder investoriem no Skandināvijas valstìm.

Vīrietis, Ādaži: Banku darbïbas apdraudējums ir pieredzēts, jo nevar izņemt naudu. Ir bijuši tādi gadījumi. Sapratām, ka jebkurā mirklī var pazust nauda. Bezskaidras naudas norēkini ir drauds.

Vīrietis, Gulbene: Lielākās bankas ir apdraudējums, jo tās nav Latvijas bankas. Finansiālās drošỉbas nav, ja to skatìtu no banku sektora.

Sieviete, Ādaži: Es uzskatu, ka skandināvu bankas ir pozitīivi, jo 2008. gadā pārstäja dot kredìtus, bet tomēr SEB banka deva.

Kā papildu risks tiek atzīmēta banku filiāḷu darbību apturēšana/samazināšana mazajās pašvaldībās un neapmierinātība ar bankomātu pieejamību. Kopumā vērtējams, ka iedzīvotājiem ir būtiska kontrole pār iespēju tikt pie skaidras naudas līdzekḷiem. 
Vīrietis, Gulbene: Bankomāti ir, bet SEB filiāle no 5 dienām pārgāja uz 3 dienām.

Citadele tikai vien̄̄gā palikusi. Bet šāda samazināšanās ir visur reǵionā.

\section{Eiropas Savienības fondi}

Pretrunīgu vērtējumu lielākajā dạ̧ā fokusa grupu ir guvušas valsts un ES investīcijas uzņēmējdarbībā un ekonomikā. Lielākā daḷa aptaujāto uzsver ES investīciju nozīmīgumu, norādot, ka tās ir būtiski veicinājušas infrastruktūras attīstību un nodrošinājušas iedzīvotāju un uzṇēmumu ieņēmumus. Tomēr vienlaikus ES investīcijas tiek vērtētas arī kā potenciāls ekonomiskās drošỉbas drauds, jo iedzīvotājos valda viedoklis, ka, mainoties ES politiskajai un ekonomiskajai situācijai un samazinoties ES investīciju apjomam, Latvijas ekonomikas izaugsme var piedzīvot strauju kritumu un iedzīvotāju labklājība var samazināties. Tāpat situāciju var ietekmēt ne tikai ar ES saistīti ārpolitiskie jautājumi, kā to norādījis vīrietis no Madonas:

Ekonomiskā situācija ir stabilāka. Lìdz ko problēmas ar Krimu, tā samazinājās eksports uz Krieviju. Trūkst darbaspēks.

[Brexit] kaut vai pastarpināti atstās iespaidu uz Latvijas procesiem. Lìdz ko ES vājāka, tā tas negatīvi ietekmē mūs. ES fondi kḷ ūst mazāki.

\section{Ekonomiskā drošība pašvaldībās}

Intervijās ar pašvaldību vadītājiem bija novērojama tendence, ka vairāku pašvaldību pārstāvji kā nozīmīgus izcēluši arī jautājumus, kurus iedzīvotāji retāk minējuši fokusa grupās. Piemēram, pretstatā iedzīvotāju biežāk pieminētajām bažām par nodokḷu sistēmas, atalgojuma, valsts pārvaldes politikas un nodokļu sistēmas prognozējamību un banku sektora ietekmi uz ekonomisko drošību, pašvaldību pārstāvji ievērojami biežāk ekonomiskās drošỉbas jomā par prioritāti uzskata jaunu uzņēmumu veidošanu, darba vietu skaita pieaugumu, ekonomisko un sociālo atšķirību starp reǵioniem izlīdzināšanu, pieeju ES fondiem, kā arī mājokḷu jautājumu risināšanu.

Pašvaldību pārstāvju sniegtajās atbildēs par būtiskākajiem ekonomiskās drošības izaicinājumiem bija vērojama tendence, ka pēc iedzīvotāju skaita mazāko pašvaldību pārstāvji kā būtisku ekonomiskās drošības problēmu min neapmierinošu pakalpojumu pieejamību un ierobežotas ekonomiskās aktivitātes iespējas iedzīvotājiem. Tas veicina iedzīvotāju neaizsargātību un migrāciju. Mazākās pašvaldībās ir mazāk iespēju un līdz ar to cilvēki ir neaizsargātāki, tāpēc biežāk izvēlas migrēt uz ārvalstīm vai citu pašvaldību - tā situāciju raksturo pašvaldību pārstāvji. Piemēram, Gulbenes pārstāvis norāda, ka Gulbene pēc iedzìvotāju skaita un ekonomiskās attīstības rādītājiem atpaliek no tādām 
reg̣ionu pilsētām kā Valmiera, tāpēc pašvaldībai ir mazākas iespējas, piemēram, ieviest tādus uzñēmējdarbību veicinošus instrumentus kā biznesa inkubatori vai arī nodrošināt augstākās izglîtības iegūšanu Gulbenē. Šie faktori pašvaldības pārstāvja vērtējumā kopumā veicina gados jaunu cilvēku aizplūšanu no mazām pašvaldībām, ko vēl vairāk veicina arī iedzīvotāju atalgojuma līmeņa atš̌kirības dažādās pašvaldībās. Kopējā labklājības līmeņa izteikto atšķirību izjūt arī pašas pašvaldỉbas, cenšoties piesaistìt sev darbiniekus.

Algas lìmenis zems, bet ne administrācijā. Bet pat pašvaldïbu darbiniekiem ir zems algas lìmenis salīdzinājumā ar citām pašvaldībām..$^{13}$

Lielāku un ekonomiski attīstītāku pašvaldību priekšrocības, kas veicina sabiedrības ekonomisko drošību, atzīst arī vairāku lielo pašvaldību, piemēram, Daugavpils, Liepājas un Valmieras, pārstāvji. Pēc Valmieras pašvaldības pārstāvju teiktā, lielākām pašvaldībām ir vieglāk veicināt iedzīvotāju ekonomisko drošîbu un novērst to migrāciju, kā arī piesaistìt darbaspēku un uzṇēmējus, arī pateicoties infrastruktūrai un pakalpojumu pieejamībai, piemēram, slimnīcām.

Slimnīca ir baigais pluss. Cilvēki izvēlas Valmieru [dzīvošanai], jo slimnīca blakus. $^{14}$

\section{Ekonomiskā stabilitāte - ienākumi un uzkrājumi}

Intervijas ar pašvaldību pārstāvjiem arī apliecina, ka kopumā viṇi ir salīdzinoši labi informēti par to, kādi ekonomiskās drošības izaicinājumi ir nozīmīgākie iedzīvotāju vērtējumā, tomēr daudzos gadījumos pašvaldību redzējums par iespējamajiem problēmu risinājumiem atšķiras no iedzīvotāju viedokḷa. Pretstatā iedzīvotājiem, kuri par būtisku problēmu uzskata to, ka trūkst labi atalgotu darba vietu, vairāku pašvaldību pārstāvji sabiedrības ekonomiskās drošības izaicinājumus saista ar neapmierinošu uzñēmējdarbības aktivitāti un darbaspēka trūkumu, kā arī dažos gadījumos pašvaldības ekonomiskās labklājības atkarību no ierobežota skaita uzn̦ēmumu. Vairāku pašvaldību, piemēram, Aizkraukles, Gulbenes un Talsu, pārstāvji uzsver - pašvaldība par savu nozīmīgāko uzdevumu uzskata piemērotas infrastruktūras izveidi pašvaldības teritorijā, lai ar tās palīdzību radītu labvēlīgus apstākḷus uzṇēmējdarbības attīstỉbai, tomēr pašvaldỉbai pieejamie atbalsta pasākumi nav garantija jaunu uzṇēmumu izveidei, - ja sabiedrībai nav intereses par uzņēmējdarbỉbas uzsākšanu vai attīstību, tad pašvaldíba to nevar tai uzspiest. 
Nav novērojama industrijas attīstība. Gulbenes vājība ir 2-3 spēcīgi uzņēmumi, bet vairāk nekā. Tas atsaucas arī uz citu cilvēku izvēli dzīvot vai nedzīvot Gulbenē. Pašvaldība sper nozīmīgus soḷus. Daudz izdarìts infrastruktūras, īpaši ceḷu sakārtošanai. Labs, saistošs piedāvājums jauniem uzn̄èmējiem ir grantu konkurss katru gadu. Konkursa ietvaros turklāt summa cēlās no 3000 EUR atbalsta uz 5000 EUR. Konkrēta pašvaldības iniciatīva. ${ }^{15}$

Pašvaldība var jau sakārtot infrastruktūru, bet uzņēmumiem ir jāveido šis darba vietas. Talsu geogräfiskais novietojums ir plus punkts, infrastruktūra ir sakārtota, pozitìva situācija ir, ka Talsu novadā atrodas biznesa inkubators. Uzn̄ēmēju kopums tiekas ar pašvaldību. ${ }^{16}$

Savukārt Aizkraukles pašvaldības pārstāvis atzīst: neskatoties uz to, ka kopējā uzṇēmējdarbības aktivitāte pilsētā ir vērtējama kā salīdzinoši laba, ne visos gadījumos uzṇēmēji ir ieinteresēti pietiekami aktīvi sadarboties ar pašvaldību un censties izmantot visas tās piedāvātās atbalsta iniciatīvas.

Vairums pašvaldību uzsver, ka par ekonomisko drošību veicinošu faktoru uzskata arī pašvaldības teritorijā esošās uzṇēmējdarbības daudzveidību, un uzsver nepieciešamību panākt mazo un vidējo uzṇēmēju skaita pieaugumu, šādi sekmējot kopējo pašvaldības iedzīvotāju ekonomisko drošumu. Liepājas pašvaldības pārstāvis norāda, ka pilsētas attīstības vēsturē jau ir pierādījies, ka l,oti lieli, šauri specifiskā uzṇēmējdarbības jomā strādājoši uzṇēmumi var kḷūt arī par sociālekonomiskās drošības risku.

Metalurgs bankrotēja 1. reizi, 1500 darbinieki zaudēja darbu. 2. reizi bankrotēja800 cilvēki. Atrada Liepājā citus uzn,ēmumus. Pārkvalificējās, meklē darbu ārpus Liepājas, pēc tam - Latvijas. Strādājošo skaits pieaudzis no 28000 lìdz 30000 tagad. Bankrota krīze pārvarēta. Negribam degradētu vidi un primitìvu produktu ražošanu. Modernas, zal̦as idejas gribam. Negribam šāda monstra atgriešanos, bet gan vidējus uzņēmumus - maksimums lìdz 500 darbiniekiem [vairāki uzṇēmumi ir apvienojušies koncernā].

Savukārt Valmieras pārstāvis norāda, ka, veicinot uzṇēmējdarbībai labvēlīgas vides attīstību pašvaldības teritorijā, pilsētai ir iespējams panākt ievērojamu ekonomiskās drošỉbas pieaugumu visai sabiedrībai un, piemēram, būtiski samazināt bezdarba līmeni.

Valmierā darba vietas ir ievērojami vairāk kā darbspējas vecumā cilvēki. Inženiertehniskā infrastruktūra balstīta uz uznēemējiem, ražotājiem. Gāzes, elektrības 
infrastruktūra piemērota 19000 darba vietām, bet iedzīvotāji darba spējas vecumā ir virs $15000 .^{17}$

Pašvaldības pārstāvis uzsver, ka Valmierai, pateicoties tās izvēlētajai ekonomiskās attīstības politikai un uzñēmējdarbības atbalsta pasākumiem, ir izdevies ne tikai ievērojami uzlabot pilsētas iedzīvotāju nodarbinātības rādītājus, bet arī piesaistìt pilsētā strādājošajiem uzṇēmumiem darbaspēku no citiem reǵioniem. Raksturojot šo tendenci, pašvaldības pārstāvis uzsver, ka, pēc CSP datiem, Valmierā ir 23000 iedzīvotāju, bet pie Valmieras gimenes ārstiem ir reg̣istrējušies 33000 iedzīvotāju. Tas norāda uz to, ka savu ikdienu ar Valmieru, visticamāk, saista ievērojami lielāks skaits iedzīvotāju, kuri dzīvo citās pašvaldībās un kurus ir piesaistijušas darba tirgus iespējas. Valmiera savu pilsētplānošanu līdz ar to ir paredzējusi 30000 iedzìvotāju, ņemot vērā abus šos informācijas avotus.

3\% bezdarbs - tie ir cilvēki, kuri dzìvē nekad nav strādājuši tā kārtīgi. Ik pa brīdim atnāk kāds jauns uzñēmums... No apkārtējiem novadiem ap 40\% brauc strādāt uz Valmieru. Apsekojumi rāda, ka 30-50 km rādiusā cilvēki ir gatavi braukt uz Valmieru. ${ }^{18}$

\section{Pabalsti un sociālais nodrošinājums}

Raksturojot situāciju ar sociālo aprūpi un pabalstiem, pašvaldību pārstāvji uzsver, ka kopumā pašvaldību iespējas sniegt atbalstu iedzìvotājiem, attīstot sociālo infrastruktūru un nodrošinot atbalstu krīzes situācijās, uzlabojas un ka, piemēram, notiek investīcijas sociālās aprūpes centros, lai sniegtu atbalstu pensijas vecuma cilvēkiem. Madonas pašvaldības pārstāvis norāda: lai gan trūcīgo iedzīvotāju skaits samazinās, pašvaldības sociālais budžets un pabalstu apjoms tiek palielināts. Piemēram, pašvaldība ir radusi iespēju palielināt bērna piedzimšanas pabalstu līdz 150 EUR un arī sniegt pabalstu gimenēm skolas mācību līdzekḷu iegādei.

Tomēr vienlaikus pašvaldību pārstāvji atzīst, ka citu sociālās palīdzības instrumentu darbība ne vienmēr ir apmierinoša, piemēram, nodarbinātības veicināšanai paredzētās apmācības un bez darba esošo iedzivotāju pārkvalificēšanās pasākumi dažkārt ir raksturojami kā nepietiekami efektīvi, jo netiek kontrolēta šo apmācību un kvalifikācijas paaugstināšanas pasākumu efektivitāte un atbilstība tautsaimniecības un uzṇēmēju pieprasijumam. $\mathrm{Ne}$ reti darba meklētājs pat pēc vairāku apmācību kursu beigšanas tomēr neatrod 
piemērotu darbu un nesniedz atbilstošu pienesumu tautsaimniecībai, uzsver pašvaldībās.

\section{Valsts pārvalde un nodokli}

Vairākās pašvaldībās to pārstāvji, vērtējot kopējo valsts pārvaldes un nodokḷu sistēmas ietekmi uz ekonomisko drošibu, pauda kritisku viedokli par valsts un pašvaldību reformu plānošanas procesu, norādot, ka bieži vien reformas tiek plānotas, nepietiekami ņemot vērā reǵionos vērojamās attīstības tendences un arī nepietiekami izvērtējot to ietekmi uz dažādām ekonomiskajām norisēm regionos. Kā vienu no problēmām reg̣ionu attīstỉbas plānošanā pašvaldību pārstāvji minēja faktu, ka transporta infrastruktūras un atjaunošanas plānošanā nepietiekami tiek ņemti vērā iedzìvotāju apsvērumi par mobilitāti un plānošanas process netiek pietiekami piesaistīts demogrāfiskās un ekonomiskās aktivitātes tendencēm un prognozēm.

Savukārt, komentējot nodokḷu sistēmas efektivitāti, pašvaldību pārstāvji ir atzinuši, ka kopumā pašvaldībām ir salīdzinoši neliela ietekme uz kopējo nodokḷ sistēmu un ka pašvaldíbas kompetencē neietilpst nodokḷ sistēmas kopējās efektivitātes kvalitatīvs novērtējums. Tomēr kopumā pašvaldības netiešā veidā izjūt to, ka nodokḷu sistēmā ir neapmierinoša ilgtermiņa plānošana.

Pašvaldībai nav ilgtermina nodokḷ viżija. Manuprāt, jābūt piecgades plānam.

Vērtējot līdzekḷu izlietojuma caurspīingumu un pamatotỉbu valsts pārvaldē, pašvaldību pārstāvji pauduši viedokli, ka nodokḷu politika un rīkotie iepirkuma konkursi kopumā ir pietiekami caurspīiñgi, tomēr daḷai sabiedrības kopumā pietrūkstot kompetences, lai to novērtētu.

\section{Banku sektors un to pakalpojumu pieejamība}

Mazākās pašvaldībās satraukumu rada bankomātu trūkums un filiāḷu slēgšana, kas ievērojami ierobežo pakalpojumu pieejamību iedzīvotājiem. Pašvaldības uzsver, ka šādos gadījumos notiek pārrunas ar bankām, lai nodrošinātu pakalpojumu nepārtrauktību.

Aizkrauklē ir tikai viens bankomāts, kurš pieejams uz ielas. Jaunjelgavā vispār tikai viens - tas pats aiz slēgtām durvīm. ${ }^{19}$

Tomēr pašvaldību pārstāvji apzinās, ka, ņemot vērā demogrāfiskās tendences, bankām nav izdevīgi uzturēt filiāles nerentablās apkaimēs. Madonas pārstāvis norādīja, ka trūkst valstiska mehānisma šai problēmai. Pašvaldību

19 Padzilinātā intervija ar Aizkraukles novada pašvaldības darbinieku. 
vērtējumā iespējamie šìs problēmas risinājumi varētu būt valstij piederošas kredītiestādes vai finanšu pakalpojuma tîkla izveide vai arī normatīvais regulējums, kurš motivētu finanšu pakalpojumu sniedzējus uzturēt šādu infrastruktūru. Gulbenes pārstāvis stāstīja, ko dara pašvaldība, lai pensijas vecuma iedzīvotāji iegūtu skaidrību par banku darbību.

Bibliotēkās daudz dara, lai izglìtotu sabiedrības vecāko daḷu saistībā ar izmainām banku darbībā. Degvielas cenas ir nozīmīgs ekonomikas drauds, jo cilvēkiem ir nepieciešams pārvietoties. ${ }^{20}$

\section{Eiropas Savienības fondi un ārpolitika}

Salīdzinot ar iedzīvotāju fokusa grupās pausto viedokli, pašvaldību pārstāvji ekonomiskās drošības kontekstā ievērojami lielāku nozīmi pieškir atbalsta un investīciju līdzekḷu pieejamībai no ES fondiem. Kā norāda pašvaldības, ES kohēzijas politikas ietvaros realizētie projekti tām ir vieni no nozīmīgākajiem instrumentiem attīstības veicināšanai, jo dažos gadījumos tie veido vairāk nekā $66 \%$ no pieejamā finansējuma visiem attīstības projektiem. Pašvaldību pārstāvji atzīst, ka, lai gan iedzīvotāji nereti ilgtermiņa budžeta plānošanai un investīciju pieejamībai pievērš maz uzmanības, tomēr kopumā pieejamie līdzekḷ pašvaldības attīstībai ir ḷoti būtisks priekšnosacījums tās ekonomiskās attīstîbas veicināšanai, un šì brīža situāciju pašvaldības vērtē ar bažām, norādot uz iespējamo pieejamo līdzekḷu samazinājumu nākamajā ES finansējuma plānošanas periodā.

Tiek norādīts, ka, samazinoties šim finansējumam, var apstāties lielākie infrastruktūras projekti, piemēram, ēku atjaunošanas, èku siltināšanas aktivitātes. Turklāt šobrīd pašvaldībām nav iespēju aizṇemties līdzekḷus Valsts kasē, un līdz ar to ES kohēzijas politikas projekti ir būtiskākais finanšu instruments pašvaldību attīstībai. Vienlaikus pašvaldību pārstāvji līdz šim sasniegto ES fondu finansējuma ietekmi uz ekonomisko drošỉbu vērtē atzinīgi, uzsverot, ka līdzšinējo projektu realizācijas gaitā ir sekmīgi izdevies iesaistît arī uzņēmējus un nevalstiskās organizācijas, šādi nodrošinot sabiedrības līdzdalību. Papildus jāatzīmē Rēzeknes pārstāvja paustais par finansiālām atškirīiām starp novadiem, sasaistot to ar ārpolitisko jautājumu.

Latgale dara nepareizi, veidojot labas attiecības ar kaimiņvalstìm. Tas arī ekonomiskajā politikā ir atspoguḷots, ka Latgale saņem mazāko finansiālo atbalstu [visiem jau zināms fakts] salīdzinājumā ar citiem reǵioniem. Un, protams, $k a$ 
ši informācija ir pieejama un cilvēki to loti labi saprot, un nekas nenotiek pretējā virziena. ${ }^{21}$

\section{Mājoklu pieejamība}

Kā īpaši būtisku problēmu, kas apdraud sabiedrības ekonomisko drošǐbu un attīstības perspektīvas daudzās pašvaldībās, pašvaldību pārstāvji min mājoklu pieejamību, kas ir saistīta gan ar īrei pieejamo mājokḷu trūkumu, gan iegādei pieejamo mājokḷu skaitu un jaunu mājokḷ būvniecības aktivitāti. Mazās pašvaldības norāda, ka nevar aṭ̦auties finansēt jaunu mājokḷu celtniecību. Savukārt Valmierā, kurā ir nodarbināts arī relatīvi liels skaits iedzīvotāju no citām pašvaldībām, secināts, ka liela dạ̦a no pilsētas infrastruktūras ir pietiekama, lai pilsētā strādājošos iedzīvotājus izmitinātu arī pašā Valmierā, tomēr nepietiekams ir tieši mājokḷu skaits.

Cilvēki fiziski nevar atrast mājokli Valmierā - skolas ir, darbs ir, slimnīca, izklaide ir. Bankas un valsts negrib finansēt mājoklı jautājumus... Fiziski to iedzìvotājus varētu pie sevis dabüt.22

Pašvaldību pārstāvji sagaida aktīvāku valsts iesaisti šĩ jautājuma risināšanā un uzsver, ka šobrīd dzīvokḷi tiek piešķirti tikai atsevišķām sociālajām grupām, tomēr būtu nepieciešams valsts atbalsts tādām programmām, kas veicina plašāku mājokḷu pieejamību visai sabiedrībai, un arī dzīvojamā fonda uzturēšanai.

Pirmkārt, noveco dzīvojamais fonds, kas nozīmē, ka iziet no aprites gan dzīvokl̦i, gan mājas, un ar kaut ko vajag aizvietot. Un ja mēs plānojam, bet plāni tādi ir - apturēt cilvēku aizplūšanu un sākt palielināt iedzīvotāju skaitu. Tas nozīmēe, ka vajag organizēt tādas programmas, kas būtu saistītas ar daudzdzīvokḷ māju būvniecību. Mès pagaidām plānojam piesaistìt privāto kapitālu, un tā konjunktūra ir tāda, ka arì Rēzekne var sev aţ̦auties būvēt, un tad tā nomas maksa būs atbilstoša, lai cilvēki spētu maksāt, un tā maksa arì segtu visus saistītos izdevumus ar mājas būvniecību un uzturēšanu tālāk. Noteikti šeit ir jābüt valsts politikai, kas stimulēs to. ${ }^{23}$

Savukārt, analizējot pašvaldību attīstības plānošanas dokumentus, secināms, ka kopumā pašvaldību pārstāvju intervijās paustie viedokḷi lielā mērā ir bijuši atbilstoši arī plānošanas dokumentos izvirzìtajām prioritātēm. 
Tā, piemēram, Aizkraukles pašvaldības izstrādātajā attīstības dokumentā "Aizkraukles novada integrētās attīstîbas programma 2013.-2020. gadam"24 par prioritāti ekonomikas jomā teikts: "Daudzpusīgas ekonomikas, kas vērsta uz ražošanas un pakalpojumu attīstību un pievienotās vērtības palielināšanu, veicināšana, sekmējot gan pilsētvides, gan lauku izaugsmi.” Kopumā iecerētās aktivitātes prioritātes veicināšanai pašvaldība ir izvirzỉjusi sasniedzamā apjomā un lielāko daļu no tām arī ir sekmīgi ìstenojusi, tostarp ielu tīkla optimizāciju, inženierkomunikāciju izbūvi un pilnveidi rūpnieciskajās zonās, uzṇēmējdarbībai paredzēto teritoriju attīstīšanu un iekḷaušanu pilsētvidē, inženiertehniskās infrastruktūras un ceḷu uzlabošanu u. c. Pašvaldība atbilstoši savām izvirzịtajām prioritātēm būtisku uzmanību pievērsusi un ìstenojusi atbilstošus pasākumus arī darbaspēka pieejamības veicināšanai tās teritorijā, uzsverot, ka sasniegts ir arī rezultatīivais rādītājs pieejamo mācību programmu skaita palielināšanai novadā, galvenokārt nodrošinot mācību programmu skaita palielināšanos Aizkraukles Pieaugušo izglìtỉbas un inovāciju atbalsta centrā, kas piedāvā 36 mācību programmas galvenokārt uzṇēmēju pieprasìtajām specialitātēm darba tirgū.

Savukārt Madonas novadā pašvaldības attīstības plānošanas dokumentā 2013.-2038. gadam ${ }^{25}$ būtiskākās ekonomiskās attīstības prioritātes ir formulētas atšķirīgi, paredzot mazāk intensīvas aktivitātes uzṇēmējdarbības piesaistei tiešā veidā un lielāku atbalstu transporta infrastruktūras attīstīšanai. Šādu attīstības politikas izvēli lielā mērā nosaka arì Madonas novada formulētās uzṇēmējdarbības prioritātes. Novads sevi saredz kā teritoriju, kurā augsta prioritāte piešķirta dabas vērtību saglabāšanai un ar dabas resursu apguvi un izmantošanu saistìtu nozaru attīstībai, piemēram, mežizstrādei, lauksaimniecībai un tūrismam. Dokumentā gan nav sniegtas tiešas atsauces uz iespējamajiem pašvaldības plāniem aktīvi iesaistīties tādu pasākumu īstenošanā, kuri veicina uzņēmējdarbībai nepieciešamā darbaspēka atrašanu.

Valmieras pašvaldības sagatavotajā dokumentā "Valmieras pilsētas ilgtspējìgas attīstības stratēgiija 2015.-2030. gadam"26, līdzīgi Aizkraukles attīstības plānam, liela nozīme ir pieškirirta pilsētas uzṇēmējdarbỉbas attīstības vēsturisko tendenču saglabāšanai un jaunu ražošanas uzņēmumu plašai piesaistei. Arī šajā gadījumā pašvaldība savu prioritāšu veicināšanai ir izraudzījusi konkrētu aktivitāšu kopumu, tostarp pilsētā pieejamo industriālo teritoriju saglabāšanu

24 Pieejams: http://aizkraukle.lv/wp-content/uploads/2018/01/ap_1_dala.pdf

25 Madonas novada ilgtspējigas attīstìbas stratēgija 2013.-2038. gadam. Pieejams: https://madona.lv/ lat/box/files/PlanosanasDokumenti/attstbas_stratija.pdf

26 Pieejams: https://www.valmiera.lv/dokumenti/valmieras-pilsetas-ilgtspejigas-attistibas-strategija2015-2030-gadam/ 
un jaunu iespējamo attīstîbas teritoriju plānošanu, kā arī bijušo industriālo teritoriju revitalizāciju. Uz uzņēmējdarbības atbalstu vērsta pieeja Valmieras pilsētas pašvaldības attīstības plānā ir vērojama arī citās attīstības jomās, piemēram, mājokḷu politikā. Pašvaldības plānošanas dokumentā pašvaldība arī pilsētas ekonomikas attīstību, iekḷaujošu pilsētvidi un sociālo infrastruktūru cieši saista ar iedzīvotāju drošỉbu, minot tās kā vienlaicīgi îstenojamus stratēgiskus mērķus.

Savukārt Gulbenes novada attīstības plānošanas dokumentā 2018.2024. gadam ${ }^{27}$ formulētās prioritātes ekonomiskās drošỉbas veicināšanas jomā ir bijušas līdzīgas Madonas novada prioritātēm, un kā perspektīvāko savas tālākās ekonomiskās attīstības virzienu novads saredz jau esošās ekonomiskās struktūras saglabāšanu, par prioritāriem uzskatot ar dabas resursu apgūšanu un izmantošanu saistîtu uzņēmējdarbỉbas nozaru attīstību (piemēram, lauksaimniecību, mežizstrādi un tūrismu). Lìdz ar to galvenās novada prioritātes ir transporta infrastruktūras saglabāšana un attīstǐšana, tūrisma infrastruktūras attīstība, vides aizsardzība, savukārt kā novada vājās vietas novada pašvaldība identificējusi ierobežotu teritoriju pieejamību industriālajai apbūvei.

Kopumā, salīdzinot minēto un arī citu pašvaldību attīstîbas plānošanas dokumentus, ir vērojama tendence, ka pašvaldības lielākajā daḷā gadījumu plānošanas procesā ir n̦ēmušas vērā pilsētu un novadu vēsturiskās attīstības tendences un tām raksturīgo sociālekonomisko struktūru. Lielākā daḷa to plānoto aktivitāšu ir vērstas uz šī pašvaldības vēsturiskās attīstības virziena saglabāšanu. Pašvaldībām, kuru vēsturisko attīstību ir būtiski ietekmējusi industriālā attīstība, kopumā ir raksturīga lielāka interese par industriālo investīciju piesaisti un ražošanas attīstībai nepieciešamās infrastruktūras nodrošināšanu, bez tam arī prioritātes citās jomās, piemēram, mājokḷu politikā un izglìtībā, šajās pašvaldībās tiek formulētas, vairāk balstoties uz uzṇēmējdarbības un nodarbinātības veicināšanas apsvērumiem. Savukārt pašvaldībās ar zemāku vēsturisko industrializāciju un augstāku lauksaimniecības un mežrūpniecības ìpatsvaru ievērojami lielāks uzsvars likts uz vides saglabāšanu, tūrisma veicināšanu, iedzīvotāju dzīves vides pilnveidošanu un vispārējās izglīīibas kvalitātes paaugstināšanu, bet mazāks uzsvars - uz ekonomiskās aktivitātes veicināšanu.

27 Gulbenes novada attīstības programma 2018.-2024. gadam. Pieejams: https://www.gulbene.lv/lv/ doks/pld/313-gulbenes-novada-attistibas-programma-2018-2024-gadam 


\section{Secinājumi}

Apkopojot būtiskākos secinājumus par pētijumā veiktajām intervijām ar iedzīvotājiem un pašvaldībām, apstiprinās iepriekš veikto aptauju iegūtais rezultāts, ka kopumā ekonomiskās drošības draudi Latvijas sabiedrībā tiek uzskatīiti par vieni no nozīmīgākajiem, ar kuriem jāsaskaras Latvijas sabiedrībai, un tie ir vērtējami kā būtiskāki nekā, piemēram, militārie draudi, dabas katastrofas vai vides piesārņojums, sociālie izaicinājumi. Vienlaikus sabiedrībā nepārprotami dominē arī viedoklis par to, ka ekonomisko draudu novēršana (labklājỉbas un ekonomiskās ilgtspējas veicināšana) ḷautu būtiski samazināt draudus arī citās sabiedrības dzìves jomās. Praktiski visās pašvaldībās iedzīvotāji fokusa grupas intervijās ir pauduši viedokli, ka pietiekams ekonomiskās labklājỉbas līmenis ir obligāts priekšnosacỉjums tam, lai valsts varētu stiprināt savas militārās spējas, aktīvāk iesaistīties vides piesārņojuma un klimata pārmaiṇu problēmu risināšanā un risināt citus līdzīgus uzdevumus, kas saistīti ar draudu novēršanu. Iedzīvotāji uzsver, ka, pirmkārt, valstij ir jābūt pietiekami turīgai, lai tā varētu aț̣auties sniegt ieguldījumu savu militāro spēju stiprināšanā, kā arī vides problēmu risināšanā, un, otrkārt, tikai pietiekami augsts iedzīvotāju labklājības līmenis attaisno valsts aktivitātes šajā jomā. Var secināt: kamēr iedzivotājus neapmierina viṇu labklājības līmenis, valstij, pēc iedzīvotāju domām, ir jāiegulda līdzekḷi militāro spēku attīstỉbā tikai ierobežotā, minimālā apjomā. Arī valsts tēriṇi vides un klimata politikas jautājumu risināšanai un draudu samazināšanai apstākḷos, kad iedzīvotājus neapmierina viṇu labklājības līmenis, drīzāk tiek vērtēti kā nevēlami.

Aptaujās tika norādīts, ka Latvijā aktuālākās ekonomiskās problēmas ir dārdzība un augošās cenas, tomēr fokusa grupās iegūtā informācija par to neliecināja. Apstiprinājās gan, ka Latvijas iedzīvotāji par salīdzinoši lielāku problēmu uzskata nodokḷu sistēmu, bet, fokusa grupās apspriežot šo problemātiku, var secināt, ka šì problēma nav saistīta ar nodokḷu apjomu, bet gan ar nodokḷu sistēmas nestabilitāti un neprognozējamību. Turklāt korupcijas gadījumi samazina vēlmi godīgi pildìt nodokḷu maksātāja pienākumus.

Iedzīvotājiem ir raksturīgs viedoklis par to, ka Latvijas ekonomisko drošību būtiski apdraud arī ārējie ekonomiskie draudi: potenciālā nedrošība banku sektora piederībai ārvalstu investoriem, atkarība no Eiropas Savienības finanšu atbalsta un investīcijām, liels ārvalstu kapitāla īpatsvars Latvijas ekonomikā, liela globālu ekonomisko krī̌̌u ietekme uz Latvijas ekonomiku. Tomēr iedzīvotāju vērtējumos vērojamas arī zināmas pretrunas, jo vienlaikus iedzīvotāji ir atzinīgi novērtējuši to, ka ES finansējums ir ḷāvis palielināt Latvijas labklājību, tāpat arī par būtisku tiek uzskatìta Latvijas uzṇēmēju konkurētspēja ārvalstu tirgos un spēja eksportēt Latvijā ražotas preces un pakalpojumus. Iedzīvotāji 
atzinīgi izteikušies arī par to, ka ārvalstu uzņēmumu investīcijas Latvijas ekonomikā veicina jaunu darba vietu radīšanu.

Tāpat fokusa grupu rezultāti apliecina to, ka ekonomiskās drošības draudi, pēc iedzīvotāju domām, ir īpaši cieši saistīti ar sociālo drošību. Nereti atsevišķās pašvaldībās to jēdzieniskais saturs praktiski saplūst, proti, ar ekonomisko un sociālo drošību tiek saprasta valsts un uzṇēmēju spēja praktiski visiem iedzīvotājiem garantēt darba vietas, kuras nodrošina minimālos ienākumus, kas ir pietiekami indivīda primāro vajadzību apmierināšanai. Šie ekonomiskās drošības draudi atklāj acīmredzamas pretrunas, jo, neskatoties uz plašas iedzīvotāju daļas vēlmi saṇemt lielu ekonomiskā un sociālā atbalsta pakalpojumu klāstu, iedzīvotāji uzskata, ka valstij no uzņēmējiem un strādājošajiem būtu jāiekasē pēc iespējas mazāki nodokḷi, kā arī jācenšas samazināt pašvaldībās un valsts iestādēs strādājošo skaitu. Tai pašā laikā novērojams, ka pašvaldību pārstāvji, runājot par ekonomisko drošību, biežāk min atkarību no ES fondu līdzfinansējuma.

Tāpat iedzīvotāju vērtējumā Latvijai ir raksturīgs nesamērīgi augsts valsts pārvaldes un pašvaldību administratīvais slogs un pārlieku liels, dārgs birokrātiskais aparāts, kura uzturēšana Latvijas iedzīvotājiem izmaksā nepamatoti dārgi un liedz ḷoti lielus līdzekḷus novirzìt dažādām citām vajadzībām, piemēram, infrastruktūras attīstībai, veselības aprūpei, sociālajām vajadzībām. Iedzīvotāji kopumā kritiski novērtējuši arī salīdzinoši biežas izmaiņas likumdošanā un nodokḷ sistēmā. Plašāk un intensīvāk komunicējot ar Latvijas iedzīvotājiem, var tikt sniegts iedzīvotājiem precīzāks priekšstats par nodokḷu slogu un valsts pārvaldes izmaksām citās ES valstīs, tādējādi veicinot kopējo iedzīvotāju izpratni par Latvijas nodokḷu sistēmas un valsts pārvaldes sistēmas konkurētspēju Eiropas Savienībā.

Papildus veiktajām fokusa grupu intervijām ar iedzivotājiem būtisku ieskatu par iedzīvotāju ekonomiskās drošības uztveri sniedza arī intervijas ar pašvaldību pārstāvjiem. Kopējā tendence liecināja, ka pašvaldībās ar salīdzinoši zemāku iedzīvotāju ienākumu līmeni un augstāku bezdarbu pašvaldību pārstāvji ir vairāk akcentējuši valsts un pašvaldību uzdevumu garantēt noteiktu sociālās un ekonomiskās labklājības līmeni iedzīvotājiem, savukārt pašvaldībās ar augstāku ienākumu līmeni un zemāku bezdarbu lielāks uzsvars likts uz pašvaldības pienākumu nodrošināt uzṇēmējdarbībai un iedzīvotāju ekonomiskajai aktivitātei stimulējošus apstākḷus. Jāuzsver, ka, salīdzinot ar iedzīvotājiem, pašvaldību pārstāvju vidū viedokḷu polarizācija starp reǵioniem ar augstāku un zemāku labklājības līmeni ir bijusi zemāka. Pašvaldību pārstāvju vidū dominē viedoklis, ka būtiskākais faktors, kas veicina ekonomisko drošību un izaugsmi, gan pašvaldībā, gan valstī kopumā ir tieši iedzīvotāju ekonomiskā 
aktivitāte. Pašvaldību pārstāvji par mazāk nozīmīgu ir uzskatījuši pašvaldību vai valsts realizēto ekonomisko politiku.

Interesanti, ka, pēc iedzīvotāju domām, pašvaldību loma ekonomiskās drošības veicināšanā ir manāmi mazāka, nekā to vērtē paši pašvaldību pārstāvji. Iedzìvotāji uzskata, ka pašvaldību rīcībā ir salīdzinoši neliels ekonomiku stimulējošu instrumentu klāsts un galvenokārt tas ir paredzēts iedzīvotāju atbalstam un infrastruktūras nodrošināšanai. Daļēji šĩ vērtējuma iespaidā lielākajā dạ̦ā aptaujāto pašvaldību (neskaitot Rīgu) iedzīvotāji ekonomikas drošības jomā pašvaldībām ir pauduši pat lielāku uzticēšanos nekā valsts centrālajai varai. Savukārt pašu pašvaldību pārstāvji, it īpaši pašvaldībās ar augstu ekonomiskās labklājības līmeni, savu lomu ekonomikas stimulēšanā ir novērtējuši kā ievērojami lielāku, uzsverot, ka daudzas pašvaldību nodrošinātās vai iespējamās funkcijas ir būtiskas, lai konkrētā pašvaldībā piesaistītu investīcijas un veicinātu darbaspēka rašanos. Tiek minēta ceḷu infrastruktūra, ùdensapgāde, izglītỉbas sistēma, sabiedriskā kārtība, kultūras pasākumi, atpūtas iespējas iedzīvotājiem, kā arī atsevišķos gadījumos mājokḷu attīstība.

Apkopojot būtiskākos secinājumus, jāsecina, ka sekmīga valsts ekonomikas politika ir vērtējama kā vitāli nozīmīgs priekšnosacỉjums valsts kopējās drošības stiprināšanai un ka viens no būtiskākajiem Latvijas valsts pārvaldes rīcībpolitikas uzdevumiem ir konkurētspējīgas uzņēmējdarbības vides un iedzīvotāju ekonomiskās aktivitātes veicināšana, uzlabojot to uzticēšanos Latvijas nodokḷu sistēmai un tiesiskajai videi, jo kopumā iedzivotājos valda viedoklis, ka ekonomikas izaugsme un iedzīvotāju labklājības pieaugums būtiski veicinās arī citu nozīmīgāko drošības apdraudējumu risinājumu, jo ekonomiskā labklājība stiprinās iedzīvotāju gatavību iesaistīties un finansēt, piemēram, militāro spēju stiprināšanu, sociālo problēmu samazināšanu, vides problēmu risināšanu. Labklājības pieaugums var sniegt arī tiešu ieguldījumu, lai veicinātu iedzīvotāju lojalitāti pret valsts pārvaldes institūcijām un drošỉbas institūcijām, šādi samazinot iespēju, ka iedzīvotāju viedokli un attieksmi pret valsts institūcijām var ietekmēt hibrīddraudi, piemēram, nedraudzīgu valstu izplatīta dezinformācija vai centieni iejaukties masu saziṇas līdzekḷu darbībā. 